www.jmscr.igmpublication.org

Index Copernicus Value: 79.54

ISSN (e)-2347-176x ISSN (p) 2455-0450

crossref DOI: https://dx.doi.org/10.18535/jmscr/v7i5.125

\title{
Hematological Abnormalities in Chronic Liver Disease: A Retrospective Study in North Bihar
}

\author{
Authors \\ Dr Sudhir Chandra Jha ${ }^{1}$, Dr Jitendra Kumar Singh ${ }^{2}$, Dr Amit Kumar ${ }^{3}$ \\ ${ }^{1}$ Associate Professor, Medicine Deptt. Darbhanga Medical College, Darbhanga \\ ${ }^{2}$ PG Resident Medicine Department (Session 2017-2020), Darbhanga Medical College, Darbhanga \\ ${ }^{3}$ Assistant Professor, Medicine Deptt, Darbhanga Medical College, Darbhanga
}

\begin{abstract}
Chronic liver disease is an end stage disease and hematological abnormalities are common finding in it, adding morbidity to primary pathology and increase the mortality. The study was conducted to assess the hematological abnormalities and haemostatic derangements in CLD patients in north bihar to reduce the morbidity. Broadly, the hematological abnormities are viewed under abnormalities in RBCS, WBCS, platelets and coagulation profile.

Methods: Total 50 patients who fulfilled our criteria were enrolled in our hospital, DMCH, Darbhanga. Patients were investigated after their oral and written consents wherever required.

Results: Various hematological abnormalities encountered were normocytic, Normo-chromic Anemia, Macrocytic mostly in alcholics, leukocytosis was more compared to leucopenia and thrombocytopenia, increased prothrombin time and APTT.

Conclusion: Every chronic liver disease patients must be evaluated for hematological abnormalities and should be treated accordingly as early possible.

Keywords: Chronic liver disease, hematological abnormalities, anaemia.
\end{abstract}

\section{Introduction}

Chronic liver disease is an end stage disease and $4^{\text {th }}$ most common cause of death in adults worldwide. In patients of CLD, the 5-years probability of decompensation (usually ascites and jaundice) is $15-20 \%$ while 5 years survival rate diseases from 84 to $14-35 \%$ once clinic decompensation developed. Liver plays an important role in normal erythropoiesis and synthesis of clotting factors and inhibitors and keeps the hemostasis in equilibrium. Liver is also site for storage of iron, vit B12 and folic acid necessary for normal hematopoiesis.
In CLD hematological abnormalities are common comborbidity. Mostly Normocytic normochromic anemia sometimes macrocytic in alcoholic coagulopathy is universal due to:

- Decreased synthesis of clotting factors and impaired clearance of anticoagulant.

- Thrombocytopenia and neutropenia due to hypersplenism leucocytosis more common than. Leucopoenia due to SBP and secondary peritonitis. 


\section{Aim of the study}

1. To study the hematological abnormalities in CLD.

2. To find out the incidence and type of anemia in CLD.

3. To detect the abnormalities in RBCs, WBC in CLD.

4. To detect plated abnormalitics coagulopathy in CLD.

\section{Materials \& Methods}

Observational study involving CLD patients was conducted at Darbhanga Medical College and Hospital, Darbhanga from March 2018 to February 2019.

50 cases were selected for the study. All the cases included were admitted in ward and evaluated for CLD and hematological abnormalities in them.

Oral and written consents were taken by patient and their attendants where required a detailed past, personal, family history, clinical examinations done and various Investigation done for the study.

\section{Investigation done:}

1. To assess RBC abnormality: RBC count hemoglobin estimation PCV, MCV, MCHC, Peripheral smear of blood.

To asses WBC abnormality: Total and differential count of WBC

To assess hemostasis: Platelet count, PT, APTT

Abdominal paracentesis

Liver biopsy

Upper GI endoscopy

Inclusion Criteria: Patients whose signs and symptoms of liver disease persist more than 6 months due to alcoholic, post-infective or metabolic cause.

\section{Exclusion Criteria}

1. Patients with known GIT malignancy or known primary hepato-cellular carcinoma.

2. Patients with primary coagulation disorder.

3. Acute liver failure.
4. Liver cell failure due to septicemia or endotoxemia other than primary liver cause.

Data Analysis: Hematological profile and hemostasis was conducted among 50 inpatients of medicine department at DMCH, Darbhanga.

Out of 50 patients, 44 are male and 6 are female:

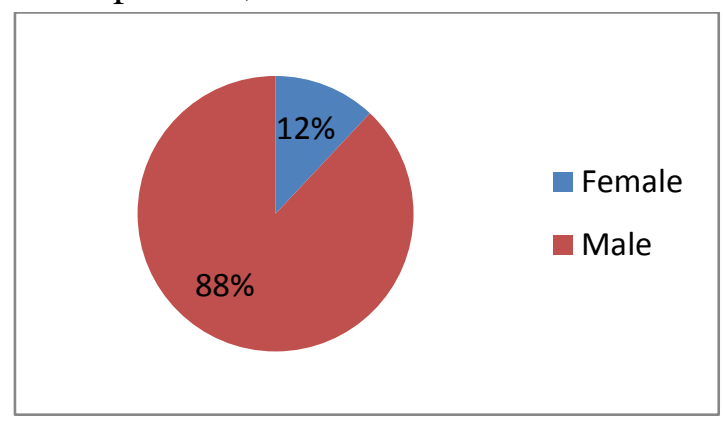

Age of patients

\begin{tabular}{|l|c|c|c|c|}
\hline Age in yrs & Male & Female & Total & Percentage \\
\hline $20-30$ & 2 & 0 & 2 & $4 \%$ \\
\hline $31-40$ & 15 & 4 & 19 & $38 \%$ \\
\hline $41-50$ & 22 & 1 & 23 & $46 \%$ \\
\hline $51-60$ & 5 & 1 & 6 & $12 \%$ \\
\hline
\end{tabular}

Out of 6 female, no one gave alcohol history and out of 44 male 30 was alcoholic. Out of 44 male patients, 10 were chronic hepatitis $B$ and out of 6 female patients 4 were chronic hepatitis B.

Analysis of RBCs: Out of 50 patients only 6 patients have normal hemoglobin.

\begin{tabular}{|l|c|c|c|c|}
\hline \multirow{2}{*}{$\begin{array}{l}\text { Hemoglobin } \\
(\mathrm{gm} / \mathrm{dl})\end{array}$} & \multicolumn{2}{|c|}{ Male } & \multicolumn{2}{c|}{ Female } \\
\cline { 2 - 5 } & Number & Percentage & Number & Percentage \\
\hline $\begin{array}{l}\text { Severe } \\
(<6 \mathrm{gm} / \mathrm{dl})\end{array}$ & 10 & $22.7 \%$ & 2 & $33.3 \%$ \\
\hline $\begin{array}{l}\text { Moderate } \\
(6-8.9 \mathrm{~g} / \mathrm{dl})\end{array}$ & 20 & $45.45 \%$ & 3 & $50 \%$ \\
\hline $\begin{array}{l}\text { Mild (9 to } \\
12.9 \mathrm{gm} / \mathrm{dl})\end{array}$ & 8 & $18.18 \%$ & 1 & $16.6 \%$ \\
\hline Normal & 6 & $13.6 \%$ & 0 & $0 \%$ \\
\hline
\end{tabular}

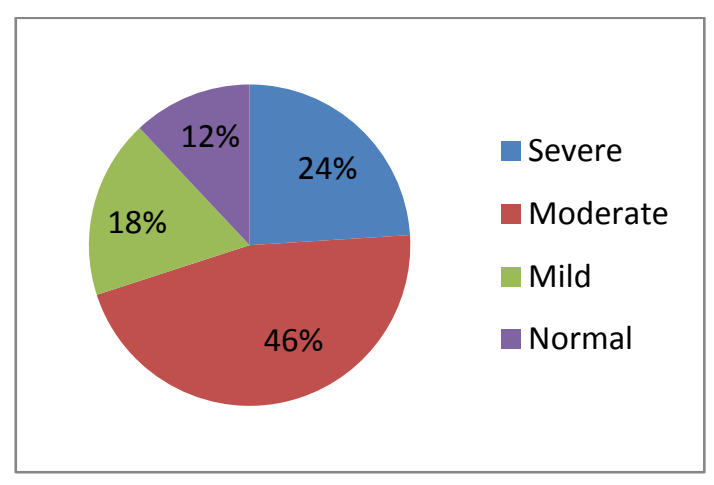


Types of Anemia

\begin{tabular}{|l|c|c|c|c|}
\hline $\begin{array}{l}\text { Types of } \\
\text { RBCs }\end{array}$ & \multicolumn{2}{|c|}{ Male } & \multicolumn{2}{c|}{ Female } \\
\cline { 2 - 5 } & Number & Percentage & Number & Percentage \\
\hline Normocytic & 23 & $52.2 \%$ & 3 & $30 \%$ \\
\hline Microcytic & 13 & $29.54 \%$ & 2 & $33.3 \%$ \\
\hline Macrocytic & 7 & $15.9 \%$ & 1 & $16.6 \%$ \\
\hline Dimorphic & 1 & $2.3 \%$ & 0 & $0 \%$ \\
\hline
\end{tabular}

\section{Platelet and coagulation abnormalities}

At our centre clotting factors can't be estimated. Platelet count, prothrombin time, international normalised ratio and activated partial thromboplastin time was estimated.

\begin{tabular}{|c|c|c|}
\hline Parameters & No. of cases & Percentage \\
\hline Platelet count & & \\
\hline$>1.5 \mathrm{lakhs} / \mathrm{mm}^{3}$ & 26 & $52 \%$ \\
\hline $1-1.5 \mathrm{lakhs} / \mathrm{mm}^{3}$ & 8 & $16 \%$ \\
\hline$<1 \mathrm{lakh} / \mathrm{mm}^{3}$ & 16 & $32 \%$ \\
\hline Prothrombin time & & \\
\hline Normal (9-12 sec) & 9 & $18 \%$ \\
\hline Prolonged & 41 & $82 \%$ \\
\hline APTT & & \\
\hline Normal (26-36 sec) & 6 & $12 \%$ \\
\hline Prolonged & 44 & $88 \%$ \\
\hline
\end{tabular}

\section{Discussion}

\section{Rbc Abnormalities}

In this study, 44 patients were male and 6 were female most of the patients were in age group. 3150 years. Most common etiology for chronic liver disease was alcohol followed by chronic hepatitis B.

$88 \%$ of patients were anaemic out of which $24 \%$ of patients were severely anaemic. A study by Rosario Gonzale $\mathrm{Z}$ - et al showed that anaemia in CLD patients were $75 \%$. According to Sheila Sherlock of oxford text book of hepatology most common anaemia is normocytic normochromic. In our study most common anaemia observed was normocytic normochromic (52\%) $16 \%$ have macrocytic, $30 \%$ had microcytic and $2 \%$ had dimorphic anaemia.

Anaemia in chronic liver disease is mostly due to:

1. Hemodilution

2. Decreased erythropoietin level as per the study sicilianohapatoy 1995 who showed decreased erythropoietin level in cirrhosis patients. Cirrhosis without anaemia is not associated with low erythropoietin levels
3. Chronic inflammation in chronic liver disease leads to increased levels of inflammatory cytokines which suppresses the bone marrow.

4. Macrocytosis in chronic liver disease is mostly due to toxicity of Alcohol on bone marrow and deficiency of vitamin $B_{12}$ and folic acid.

5. Microcytic anaemia is seen in patients who had bleeding from various Gastrointestinal sites.

\section{Abnormalities of WBCs}

In our study group of 50 patients, $32 \%$ patients had leukocytosis $\left(>11,000 \mathrm{~mm}^{3}\right)$ due to nosocomial infections, spontaneous bacterial peritonitis and secondary bacterial peritonitis. leucopenia present in $6 \%$ of patients due to :-

- Direct influence of alcohol on bone marrow.

- Chronic inflammatory cytokines having suppressor effect on bone marrow.

- Hypersplenism.

- Infection

\section{Platelet abnormalities and coagulopathy}

According to interesting article by Tody L Kujovich MD - "Hemostatic defects in end stage liver disease", critical care clinics 21 (2005), mild to moderate thrombocytopenia occurs in 49 to $64 \%$ of patients with decompendated chronic liver disease (DCLD). Platelet count is rarely less than 30 to 40 thousands $/ \mathrm{mm} 3$

In our study $48 \%$ patients had thrombocytopenia $\left(<1.5\right.$ lakhs $\left./ \mathrm{mm}^{2}\right)$

Causes of thrombocytopenia

1. Low thrombopoietin level

2. Hypersplenism.

3. Folate deficiency.

4. Alcohol induced bone marrow suppression.

5. DIC

6. Sepsis.

Escolar $\mathrm{G}$ et al reports that platelets aggregation to be particularly affected in $46 \%$ of patients of DCLD. 


\section{Possible mechanism include:}

1. Reduced availability of arachidonic acid for prostaglandin synthesis.

2. Reduced platelet ATP and serotonin.

3. Increased FDP and D-dimers nitric oxide.

4. HDL isolated from cirrhotic patients that inhibit ADP induced platelet aggregation.

5. Platelet binding domains are abnormal thus preventing efficient binding to Von Willi Brand factor.

\section{Coagulation abnormalities}

A deranged coagulation system is universal in chronic liver disease due to reduced synthesis of coagulation factors (except factor VIII and Von willibrand factor), hyperfibrinolysis and dysfibrino-genemia.

In our study $80 \%$ of patients have prolonged prothrombin time and $88 \%$ patients have prolonged APTT.

\section{Conclusions}

According to the study conduct with limited cases of 50 patients, we inferred many conclusive results regarding RBC abnormalities in CLD.

1) Most common anaemia is normocytic normochromic, microcytosisin patients having bleeding tendencics. macrocytic in alcoholic.

2) Leukocytosis more common than leukopenia.

3) Thrombocytopenia is common but prolonged PT and APTT in most of the patients.

4) All the CLD patients must be evaluated for hematological abnormalities for early correction to decrease the mortality.

\section{Bibliography}

1. McHutchison JG, Manns MP, Longo DL. Definition and Management of anemia in patients infected with hepatitis $\mathrm{C}$ virus. Liver Int. 2006; 26: 389-398. (PubMed)

2. Middle-East Journal of Scientific Research 7(6): 1001-1007, 2011 ISSN 1990-9233@ idosi publications, 2011.
3. Lindenbarum J, Lieber CS, Effects of chronic ethanol administration on intestinal absorption in man in the absence of nutritional deficiency. Ann. NY ACad.Sci, 1975, 252: 228-234.

4. Fergunson, J. Skikne, B.S, Simpson, K.M., Baynes, R.D \& Cook J.D (1992).Serum transferrin receptor distinguishes the anemia of chronic disease from iron deficiency anemia. J.Lab. Clini. Med. 1992; 19: 385.

5. Haussinger D. In:Oxford text book of hepatology II edition, Bircher J, Benhamou J, McIntyre N, Rizzetto M, Rodes J, Eds, Oxford University Press, Oxford, 1999, pg 325.

6. Kimber C, Deller DJ, Ibbotson RH, and Lander $\mathrm{H}$. The mechanism of anaemia in chronic liver disease. Quarterly Journal of Medicine, 1965; 34: 33-64.

7. Sheehy TW and Berman A. The anaemia of cirrhosis. Journal of Laboratory and Clinical Medicine, 1960; 56: 72-82.

8. Schmidt K, Waever Rasmussen JDahl Rasmussen A, Arendrup H, Comparative studies of the in vivo kinetics of simultaneously injected 111 in- and $51 \mathrm{Cr}$ labelled human platelets. Sca J. Hematol, 1983. 30: 465-78.

9. Siciliano M, Tomasello D, Milani A, Ricerca BM, Storti S, Rossi L, Reduced serum levels of immuno reactive erythropoietin in patients with cirrhosis and chronic anemia, Hepatology, 1995, 22: 1132-5.

10. Piris M, Fabris C, Soardo G, CEcchin E, Toniutto P, Bartoli E, Thrombocytopenia of chronic liver disease corrected by erythropoietin treatment. J. Hepatol, 1994, 21: 376-80.

11. Berman I, Axelord AR, and Horan TN. The blood and bone marrow in patients with cirrhosis of the liver. Blood, 1949; 4: 511-33. 
12. Sheila Sherlock. Disease of Liver, Biliary system 11th edition, 25 Oct 2007.

13. Means RT and Krantz S. Progress in understanding the pathogenesis of the anaemia of chronic disease. Blood, 1992; 80: $1639-47$.

14. Carr JM. Disseminated intravascular coagulation in cirrhosis. Hepatology, 1989; 10: 103-10.

15. Lindenbaum J. Hematologic complications of alcohol abuse. Sem. Liver. Dis, 1987, 7: 169-181.

16. Phillips DL and Keeffe EB. Hematologic manifestations of gastrointestinal disease. Hematology/Oncology Clinics of North America, 1987; 1: 207-28.

17. Review of Medical Physiology: William F Ganong 22nd edition, Regulation of gastrointestinal function, page 500 ,Functions of liver.

18. Sherlocks textbook of liver diseases 12th edition; Haematological disorders of the liver, Pramod K Misry and DhanpatJain, Para 1.

19. Sherlocks textbook of liver diseases 12th edition; Chapter 1: Anatomy and Function, Jay H. Lekowitch, Anatomy ofliver, page 1, Para 3.

20. Couinaud C. Le fois. Etudes anatomiques et chirurgicales. 1957, paris, Masson

21. Bismuth H. Surgical anatomy and anatomic surgery of liver; World Journal of surgery, 1982; 6:3 to 9

22. Sherlocks textbook of liver diseases 12th edition; Chapter 1: Anatomy and Function, page 9 , Para 4, Jay H.Lekowitch

23. Kiernan F. Anatomy of liver. 1833; 123: 711 to 770

24. Rappaport AM. The microcirculatory acinar concept of liver. Beitr.Pathol.1976

25. Schiff Hepatology 2012; Chapter 5: physioanatomic considerations, Ian $\mathrm{R}$ Wanless, Page 89, Para 2

26. Review of Medical Physiology: William F Ganong 22nd edition, Regulation of gastrointestinal

function,

page

500,Functions of liver- table 26-7

27. Robbins \&Cotrans: pathologic basis of disease; 8th Edition; chapter 18, liver and biliary tract - James M Crawford,Chen Liu, page 837 , para 1

28. Sherlocks textbook of liver diseases 12th edition; Hepatic cirrhosis, $\mathrm{P}$ Aiden McCormick, page 106, Para 2.

29. Gines P, Quintero E, Arroyo V et al. Compensated cirrhosis: natural history and prognostic factors. Hepatology 1987:122 to 128

30. Sherlocks textbook of liver diseases 12th edition; Hepatic cirrhosis, $\mathrm{P}$ Aiden McCormick, table7.2 - histopathologyand aetiology of cirrhosis.

31. Schiff Hepatology 2012; Chapter 12: Hepatic Fibrosis, Scott I Friedman, Page 299, Para 5

32. Gressneret al. Comparative Hepatology 2007 6:7

33. Davidson principles and practice of internal medicine; 21st Edition, Chapter 23: Liver and Biliary tract: J D Collier, GWebster, page 942,

34. Anbazhagan G, Mohan Raj P, Kalaivalli S, et al. Red blood cell abnormalities in Decompensate Chronic Liver Disease (DCLD). Journal of Evidence based Medicine and Healthcare 2015;2(7):826833.

35. Ray G. Trends of chronic liver disease in a tertiary care referral hospital in Eastern India. Indian J Public Health 2014;58(3):186-194.

36. Garcia-Compean D, Jaquez-Quintana JO, Gonzalez-Gonzalez JA, et al. Liver cirrhosis and diabetes: risk factors, pathophysiology, clinical implications and management. World J Gastroenterol 2009;15(3):280-288.

37. Ali M, Ananthakrishnan AN, McGinley EL, et al. Deep vein thrombosis and pulmonary embolism in hospitalized 
patients with cirrhosis: a nationwide analysis. Dig Dis Sci 2011;56(7):21522159.

38. Kalaitzakis E, Gunnarsdottir SA, Josefsson A, et al. Increased risk for malignant neoplasms among patients with cirrhosis. Clin Gastroenterol Hepatol 2011;9(2):168174.

39. Gonzalez-Casas R, Jones EA, MorenoOtero R. Spectrum of anemia associated with chronic liver disease. World J Gastroenterol 2009;15(37):4653-4658.

40. Kumar EH, Radhakrishnan A. Prevalence of anaemia in decompensated chronic liver disease. World Journal of Medical Sciences 2014;10(1):56-60.

41. Bessman JD. Reticulocytes. Chapter 156. In: Walker HK, Hall WD, Hurst JW, eds. Clinical methods: the history, physical, and laboratory examinations. 3rd edn. Boston: Butterworths 1990.

42. Popper H, Schaffner F, et al. Hematopoetic factors. In: Progress in liver diseases. 1st edn. Vol. 2. Elsevier 1965:P. 65.

43. Kujovich JL. Hemostatic defects in end stage liver disease. Crit Care Clin 2005;21(3):563-587.

44. Tan TC, Crawford DH, Franklin ME, et al. The serum hepcidin: ferritin ratio is a potential biomarker for cirrhosis. Liver Int 2012;32(9):1391-1399.

45. Aster RH. Pooling of platelets in the spleen: role in the pathogenesis of hypersplenic thrombocytopenia. J Clin Invest 1966;45(5):645-657.

46. Jacobs A, Worwood M. Ferritin in serum: clinical and biochemical implications. $\mathrm{N}$ Engl J Med 1975;292(18):951-956.

47. Caldwell SH, Hoffman M, Lisman T, et al. Coagulation disorders and hemostasis in liver disease: pathophysiology and critical assessment of current management. Hepatology 2006;44(4):1039-1046.

48. Mannucci PM, Tripodi A. Hemostatic defects in liver and renal dysfunction.
Hematology Am SocHematolEduc Program 2012;2012:168-173.

49. Harrison's principles of internal medicine $20^{\text {th }}$ edition

50. Davidson's principles and practice of medicine $23^{\text {rd }}$ edition. 